\title{
The Electric Undergrad: An interadive library program
}

\author{
By Dennis Norlin and Joyce C. Wright
}

\section{A bigh-tech, multi-media introduction to the library}

A fter two years of concentrated effort, the University of Illinois at Urbana Undergraduate Library's new interactive orientation program was dedicated December 17, 1992. As the first step in a plan to use interactive computing as a major mode of providing ready reference, bibliographic instruction, and orientation, Electric Undergrad is available on two IBM workstations at information kiosks at the entrance to the Undergraduate Library.

Through digitization of images and sounds, Electric Undergrad provides a hightech, multimedia introduction to the programs and services of the Undergraduate Library. Each segment of the program includes music, narration, graphics, text, and images, combined into short stories about 17 major undergraduate library areas: reference desk, reference collection, circulation, print indexes, periodicals area, CD-ROM area, writers'

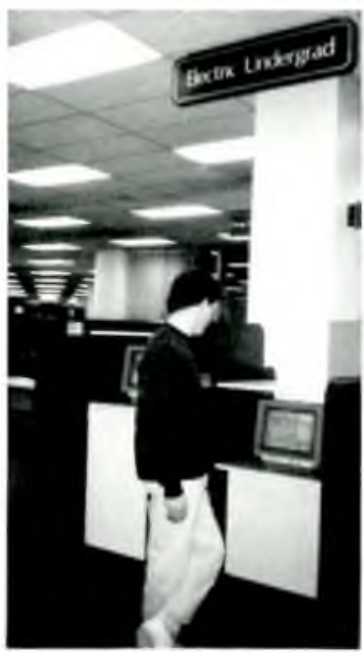

Kiosks housing the Electric Undergrad at the University of Illinois at Urbana's Undergraduate Library
Undergrad tradition that provides answers to all kinds of student questions).

Utilizing IBM PS2/57s with rewritable optical disks and the 8516 Touch Screen Monitor, the orientation program, through the use of digitized graphics, images, music, and voice, offers the user two major options to learn about the Undergraduate Library:

12-Minute Tour is a self-contained 12-minute tour of 17 different Undergrad service areas, providing a brief description and location for each.

Tour Specific Areas provides the opportunity for the user to select longer descriptions and explanations of any or all of the 17 areas highlighted in the Short Tour. From the shortest story (Reference desk) to the longest (CD-ROM), the 17 areas provide nearly 30 minutes of library orientation, occupying more than $120 \mathrm{MB}$ on the optical disk.

One of the two kiosks housing Electric Undengrad is accessible to wheelchairs, the other is designed to be used while standing. Small speakers on each side of the kiosk provide the narration and music at a level that does not disturb paworkshop, media center, microcomputer lab, interactive media center, college and career center, SHIC (Self-Help Information Center), card catalog, online catalog, browsing area, reserves desk, and question board (a time-honored trons at nearby online terminals or the information desk. The use of touchscreen monitors prevents corruption of the data, and the use of rewritable optical disks makes customization and revision of the programs convenient. 


\section{Student reaction to the Electric Undergrad}

So far students have responded positively to the Electric Undergrad, but there are plans to conduct a study. It is fascinating to see how they are examining the latest "technological toy" in the Undergraduate Library. Instructors are beginning to request that students use the Electric Undergrad instead of the library tape tour. However, it will not replace the audio tape tours, but presents a new alternative.

As academic libraries move towards Computer Assisted Instruction (CAI), we believe the Electric Undergrad will be one of the successful programs to emulate for interactive library orientation.

According to Bob Wedgeworth, interim university librarian, "The Electric Undergrad is only the first step in an evolving series of developments that will transform the Undergraduate Library into a multi-media laboratory for research and study. Among the benefits we expect to realize will be a more independent undergraduate student, capable of identifying and satisfying their information needs, whether they are course-related or intended to satisfy their own desire to learn more."

Electric Undergrad began two years ago when Media/Microcomputer Librarian Dennis Norlin (currently director of the Devereaux $\mathrm{Li}$ brary) received one of the first IBM Innovations Grants from a campus-wide committee promoting the use of interactive computing in undergraduate instruction. Additional funding for the program was provided by a grant from the Chancellor's Parents' Fund.

\section{(Internet resources cont. from page 396)}

various net inquiries. The NAFTA document is quite long and unless you have a lot of disk space available and facility for electronically storing and searching the document, you may not want to retrieve the files via ftp. You can however, search and retrieve relevant portions of the text via WAIS (Wide Area Information Server) at <sparc-1.law. columbia>.

WAIS Information of Interest to Latin Americanists. To connect to WAIS: <telnet 192.31.181.1 or quake.think.com> Login: wais. The LIBS software described above provides seamless access to WAIS. WAIS

\section{Feature your collection on the cover of C\&RL News}

CERL News wants to feature aesthetically pleasing photos of items from library collections on its covers. If you have material in your library's collections that you think would make an attractive CGRL News cover, please send us a photograph and a brief description of the item and the collection. Photos may be either color or black and white and should be $5^{\prime \prime} \times 7^{\prime \prime}$ or $8^{\prime \prime} \times 10^{\prime \prime}$. Illustrations with a vertical orientation work best. Materials submitted will become the property of CERL News and cannot be acknowledged. Send to: CERL News Covers, 50 E. Huron St., Chicago, IL 60611. allows keyword access to hundreds of archived electronic files. Browse the list to see what is available. WAIS sites and searchable files change constantly. The following files and sites currently available may be of interest to Latin Americanists: <nafta at sparc1.law.columbia>, <us-budget-1993 at sunsite.unc.edu>, <columbia-spanish-lawcatalog at pegun.law.columbia.edu $>$ $<$ clinton-speeches at sunsite.unc.edu $><$ usstate-department-travel-advisories at gopher.stolaf.edu>, and <worldfactbook(CIA) at cmns-moon.think.com>. You can also search the Kovacs list of Academic E-mail Conferences via WAIS <academic_email_conf at munin.ub2.lu.se> GOPHER UT-LANIC: Latin American Network Information Center. Produced by the University of Texas-Austin, Institute of Latin American Studies. Access via telnet: $<$ telnet lanic.utexas.edu> Login: <lanic> You can also access via any gopher server with a menu system that allows access to "all gophers in the world." Choose North America, Texas, etc. Announced in April 1993, the experimental UT-LANIC gopher offers a menu that will provide access to Latin American databases, access to library catalogs and other services. When complete it will include a directory of databases by subject and will provide automatic access through pointers. For more information contact: Ning Lin, LANIC Technical Director <nlin@bongo .cc.utexas.edu> or Carolyn Poage <carolyn@emx.utexas.edu>. 